Огляди літератури, оригінальні дослідження, погляд на проблему

УДК 616.728.2-007-053.1-053.2/.31-073

DOI 10.11603/1811-2471.2018.v0.i1.8719

\title{
СОНОГРАФІЧНА ДІАГНОСТИКА ДИСПЛАЗІЇ КУЛЬШОВИХ СУГЛОБІВ У ДІТЕЙ ДО 1 РОКУ
}

ОН. О. Марченкова

\section{ДВНЗ «Тернопільський державний медичний університет імені І. Я. Горбачевського МОз України»}

РЕзЮМЕ. Наведений аналіз результатів сонографічного обстеження кульшових суглобів 127 дітей віком до 1 року. З'ясовані переваги стандартної методики ультразвукового обстеження кульшового суглоба: ефективність 3 перших днів життя дитини, можливість динамічного обстеження, доцільність моніторингу, зокрема для виявлення вторинної дисплазії кульшових суглобів.

КлючОВІ СлОВА: дисплазія кульшового суглоба; сонографічне обстеження; діти.

Вступ. Дисплазія кульшового суглоба та вроджений вивих стегна як її крайній прояв $\epsilon$ однією з найпоширеніших та найтяжчих вроджених вад опорно-рухового апарату. В Україні ця патологія зустрічається у 3,8 \% новонароджених, а в екологічно несприятливих регіонах - в 5-7 разів частіше [3]. Слід зазначити, що причини виникнення даної патології до кінця не з'ясовані. Лікарі більшості розвинених країн дотримуються думки про можливість формування дисплазії кульшового суглоба в процесі росту дитини $[5,6]$. Тому замість терміну «congenital hip dysplasia» (вроджена дисплазія) у 1989 р. введений термін «developmental hip dysplasia» (дисплазія, яка пов'язана з розвитком). Успіх лікування даної патології залежить від ранньої діагностики, тому що при лікуванні до 3-місячного віку в 97 \% випадків досягається позитивний результат [1]. Клінічна та рентгенологічна діагностика дисплазії кульшового суглоба загальновідома, але число псевдопозитивних і псевдонегативних діагнозів становить відповідно 30-40 \% та 20-25\% [1, 7]. «Золотим стандартом» діагностики дисплазії кульшового суглоба в розвинених країнах давно визнано сонографічне обстеження, проте значна кількість практичних лікарів України і досі не довіряють даному методу.

Мета дослідження - вивчити ефективність сонографічного обстеження кульшових суглобів за методикою Графа в діагностиці дисплазії кульшових суглобів у дітей до 1 року.

Матеріал і методи дослідження. Проведено вивчення результатів сонографічного обстеження кульшових суглобів у 127 дітей (254 кульшових суглоби) віком 1-12 міс., які були обстежені в «Ортоклініці» на базі ТМКЛШД з 2016 по 2017 рр. Серед малюків було 82 дівчинки і 45 хлопчиків, середній вік становив 4,5 2,5 міс. Ультразвукове о6стеження проводили на апараті SYMENS 2000 лінійним датчиком 9Гц з використанням програмного забезпечення Pediatric hip. Використовували стандартну методику Р. Графа [4]. Дитину вкладали на бік, таким чином, щоб плечовий та тазовий пояс знаходились на одній лінії, та фіксували руками за допомогою батьків або медсестри. Нога на стороні дослідження була зігнута в кульшовому суглобі під кутом $30^{\circ}-60^{\circ}$, приведена та дещо ротована всередину. Датчик розташовували латерально від зони великого вертлюга у фронтальній площині. При отриманні зображення на моніторі досягали стандартної площини сканування: розташування клубової кістки паралельно до краю сонографічної картини без вигинів клубової кістки, зображення вертлюгової западини в іiї максимальному діаметрі з візуалізацією У-хряща, зображення хрящової губи та головки губи. Також проводили динамічне обстеження. Провокаційний тест виконували при згинанні ноги до $90^{\circ}$, максимальному приведенні, внутрішній ротації з додатковим поштовхом стегна в краніальному напрямку.

Комплексна оцінка розвитку кульшових суглобів включала в себе:

- морфологічні параметри - форма та ступінь розвитку клубової кістки, кісткового еркера, глибина та форма суглобової западини, хрящового даху, хрящової губи, ядра осифікації;

- кількісні параметри - нормативні показники кутів а і $\beta$, які характеризують відповідно кістковий і хрящовий дах;

- динамічні параметри - оцінка просторових співвідношень елементів кульшового суглоба при проведенні функціональних проб.

Всім дітям проводили повторні дослідження з інтервалом в 2-3 міс. до досягнення 1 року з метою динамічного спостереження за розвитком суглобів.

Результати й обговорення. Результати сонографічного обстеження 127 дітей віком 1-12 міс. згідно з описовою та кількісною оцінкою формування кульшового суглоба за Р. Графом та ITO АМНУ $[2,4]$ були поділені на 5 груп: вікова норма - 62 дитини; затримка формування кульшового суглоба - 47; дисплазія кульшового суглоба - 15 , підвивих стегна - 3; вивих стегна - 0 .

62 дітей (середній вік $(5,5 \pm 2,5)$ міс.) з віковою нормою сонографії мали прямокутну або дещо 
Огляди літератури, оригінальні дослідження, погляд на проблему

округлену форму кісткового еркера, хрящовий дах перекривав головку з надлишком, хрящова губа подовжена; середні показники правого кульшового суглоба: кут $a-62,3^{\circ} \pm 2,1^{\circ}$, кут $\beta-31,4^{\circ} \pm 3,7^{\circ}$; лівого кульшового суглоба: кут $a-61,8^{\circ} \pm 1,9^{\circ}$, кут $\beta-32,7^{\circ} \pm 3,1^{\circ}$.

У 28 дітей віком 4-5 міс., в яких при нормальних показниках кульшового суглоба не було сформованого ядра осифікації - представлено у вигляді штрихів звапнення довжиною 0,9-1,7 мм, тоді як при повторних оглядах у віці до 6-7 міс. у всіх було сформоване ядро осифікації розміром 4,87,3 мм.

У 15 дітей віком 2-7 міс. розмір ядра осифікації перевищував вікові норми на 2-3 мм. У інших 19 дітей діаметр ядра осифікації був $(5,0 \pm 2,0)$ мм.

у 32 дітей до 4 міс. при проведенні провокаційної проби спостерігалась нестабільність кульшового суглоба, яка зникала до 6 міс.

47 дітей (середній вік $(3,5 \pm 1,5)$ міс.) з затримкою формування кульшового суглоба мали незначно округлений кісткового еркер, хрящовий дах перекривав головку, губа вкорочена, ядро осифікації d до 3 мм. У 12 дітей була двобічна затримка формування (справа: кут а $-54,8^{\circ} \pm 1,2^{\circ}$, кут $\beta$ $58^{\circ} \pm 1,8^{\circ}$; зліва: кут $\alpha-52,3^{\circ} \pm 2,1^{\circ}$, кут $\beta-60,4^{\circ} \pm 1,4^{\circ}$ ). У 27 дітей відставав у розвитку лівий кульшовий суглоб (справа: кут $a-60,5^{\circ} \pm 0,2^{\circ}$, кут $\beta-51,2^{\circ} \pm 1,4^{\circ}$; зліва: кут $a-52,7^{\circ} \pm 2,5^{\circ}$, кут $\left.\beta-59,1^{\circ} \pm 2,3^{\circ}\right)$, у $8-$ правий (справа: кут $a-53,8^{\circ} \pm 1,2^{\circ}$, кут $\beta-59,2^{\circ} \pm 2,1$; зліва: кут $a-61,1^{\circ} \pm 0,8^{\circ}$, кут $\left.\beta-48,4^{\circ} \pm 1,9^{\circ}\right)$.

Серед 15 дітей з дисплазією кульшового суглоба (середній вік $(2,5 \pm 1,5)$ міс.) у 12 малюків патологія була встановлена при першому огляді. Вони мали круглий або сплощений кістковий еркер, хрящовий дах перекривав головку не повністю, губа вкорочена, ядра осифікації не сформова- ні (справа: кут $a-47,8^{\circ} \pm 0,5^{\circ}$, кут $\beta-63^{\circ} \pm 1,5^{\circ}$; зліва: кут $a-45,9^{\circ} \pm 1,3^{\circ}$, кут $\beta-65,4^{\circ} \pm 2,5^{\circ}$ ). У 3 дітей 3 нейрогенними та нейром'язовими порушеннями, котрі при першому обстеженні у віці 2 міс. мали нормально розвинені для свого віку кульшові суглоби, при повторному огляді у віці 5-6 міс. виявлена двобічна дисплазія.

При обстеженні 3 дітей з підвивихом стегна (середній вік $(4,5 \pm 1,0)$ міс.) у всіх виявлено відстававання у розвитку лівого кульшового суглоба. При сонографії зліва був сплощений кістковий еркер, хрящовий дах недостатньо перекривав головку, губа зміщена краніально, ядро осифікації несформоване (справа: кут а $-61,8^{\circ} \pm 0,5^{\circ}$, кут $\beta$ $48,7^{\circ} \pm 2,1^{\circ} ;$ зліва: кут $a-40,5^{\circ} \pm 1,0^{\circ}$, кут $\left.\beta-78,5^{\circ} \pm 0,5^{\circ}\right)$.

Висновки. 1. Використання стандартної методики сонографічного обстеження кульшового суглоба дозволяє його візуалізацію з перших днів життя дитини.

2. Перевагами сонографічного обстеження $\epsilon$ його безпечність, можливість динамічного обстеження в режимі реального часу, можливість неодноразового повторення до досягнення дитиною 1-річного віку.

3. Доцільне проведення моніторингу розвитку кульшових суглобів у дітей з відсутністю патології до досягнення ними 1 року з метою виявлення вторинної дисплазії кульшових суглобів.

4. Для об'єктивної оцінки кульшового суглоба слід звертати увагу не лише на кількісні, а й на морфологічні та динамічні показники.

5. При аналізі морфологічних даних не вважаємо сповільнення осифікації ядра специфічною ознакою дисплазії кульшового суглоба

Перспективи подальших досліджень. Необхідне подальше вивчення питань сонографічного обстеження кульшового суглоба у дітей до 1 року.

\section{ЛІТЕРАТУРА}

1. Вовченко Г. Я. Раннє виявлення порушень формування кульшового суглоба. Клініко-сонографічне дослідження : дис. на здобуття наукового ступеня канд. мед. наук: 14.01.20 / Г. Я. Вовченко. - Київ, 1995. - 167 с.

2. Рання променева діагностика вроджених порушень формування кульшового суглобу у новонароджених і дітей до року / О. Г. Гайко, А. Я. Вовченко, Я. Б. Куценок [та ін.] // Вісник ортопедії, травматології та протезування - 2014. - № 3. - С. 38-44

3. Прояви дисплазії сполучної тканини у новонароджених / І. В. Рой // Ортопед., травматол. и протезир. 2005. - № 3. - С. 69-73.
4. GrafR. The use of ultrasonography in developmental dysplasia of the hip / R. Graf // Acta. Orthop. Traumatol. Turc. - 2007. - No. 41 (Suppl. 1). - P. 6-13.

5. Harcke H.T. Developmental dysplasia of the hip: a spectrum of abnormality / H.T. Harcke // Pediatrics. 1999. - Vol. 103, No. 1. - P. 152.

6. Hobbs D. L. Developmental dysplasia of the hip / D. L. Hobbs, C. Mickelsen, W. Johnson // Radiol. Technol. 2007. - Vol. 78, No. 5. - P. 423-428.

7. Sewell M. D. Developmental dysplasia of the hip / M. D. Sewell, K. Rosendahl, D. M. Eastwood // BMJ. - 2009. No. 24. - 339- P. 44-54. 
Огляди літератури, оригінальні дослідження, погляд на проблему

REFERENCES

1. Vovchenko H.Ya. (1995). Rannie vyiavlennia porushen formuvannia kulshovoho suhlobu. Kliniko-sonohrafichne doslidzhennia [Early detection of violations of the hip joint formation. Clinical and sonographic research]. Candidate's thesis. Kyiv [in Ukrainian].

2. Haiko, O.H, \& Vovchenko, A.Ya., \& Kutsenok, Ya.B., \& Luchko, R.V., \& Stetsula, A.S.(2014). Rannia promeneva diahnostyka vrodzhenykh porushen formuvannia kulshovoho suhlobu u novonarodzhenykh i ditei do roku [Early radiation diagnosis of birth defects in the formation of the hip joint in newborns and children until year]. Visnyk ortopedii, travmatolohii ta protezuvannia - Bulletin of Orthopedics, Traumatology and Prosthetics, 3, 38-44 [in Ukrainian].

3. Roi, I.V. (2005). Proiavy dysplazii spoluchnoi tkanyny u novonarodzhennykh. [Manifestations of connective tissue dysplasia in newborns]. Ortopediia, travmatolohiia i protezuvannia-Orthopedics, Traumatology and Prosthetics, 3, 69-73 [in Ukrainian].

4. Graf, R. (2007). The use of ultrasonography in developmental dysplasia of the hip. Acta. Orthop. Traumatol. Turc., 41 (Suppl. 1), 6-13 [PubMed].

5. Harcke, H.T. (1999). Developmental dysplasia of the hip: a spectrum of abnormality. Pediatrics, 103 (1), 152.

6. Hobbs, D.L., Mickelsen, C., \& Johnson, W. (2007). Developmental dysplasia of the hip. Radiol. Technol., 78 (5), 423-428.

7. Sewell, M.D., Rosendahl, K., \& Eastwood, D.M. (2009). Developmental dysplasia of the hip. BMJ, 24 (339), b4454

\section{СОНОГРАФИЧЕСКАЯ ДИАГНОСТИКА ДИСПЛАЗИИ ТАЗОБЕДРЕННЫХ СУСТАВОВ У ДЕТЕЙ ДО 1 ГОДА}

ОН. А. Марченкова

ГВУз «Тернопольский государственный медицинский университет имени И. Я. Горбачевского МЗ Украины»

РЕЗЮМЕ. Приведен анализ результатов сонографического обследования тазобедренных суставов 127 детей в возрасте до 1 года. Выяснены преимущества стандартной методики ультразвукового обследования тазобедренного сустава: эффективность с первых дней жизни ребенка, возможность динамического обследования, целесообразность мониторинга, в частности для выявления вторичной дисплазии тазобедренных суставов.

КЛЮЧЕВЫЕ СЛОВА: дисплазия тазобедренного сустава; сонографическое обследование; дети.

\section{SONOGRAPHIC DIAGNOSTICS OF DYSPLASIA OF HIP JOINTS IN CHILDREN UNDER 1 YEAR OF AGE}

@N. O. Marchenkova

\section{Horbachevsky Ternopil State Medical University}

SUMMARY. The analysis of results of sonographic examination of hip joints in 127 children under one year is presented. The advantages of the standard method of ultrasound examination of the hip joint are the effectiveness from the first days of the child's life, the possibility of dynamic examination, the expediency of monitoring in particular for the detection of secondary dysplasia of the hip joints.

KEY WORDS: dysplasia of hip joint; sonographic examination; children. 